\section{Sweden must close centres or leave CERN, says council}

[MUNICH] Sweden's Natural Sciences Research Council (NFR) has warned the government that, unless budget cuts are restored, it will either have to close some national research centres or give up its membership of CERN, the European Laboratory for Particle Physics.

In an interim report delivered to the government last week, the NFR says it would recommend closing "two or three" of the national facilities, rather than leaving CERN or reducing university grant money, which has been heavily pruned in recent years.

The two most vulnerable facilities are the The Svedberg Laboratory, a particle physics laboratory in Uppsala, and the Onsala Space Observatory near Gothenburg, which has two radiotelescopes.

Last year the Swedish government imposed a 14 per cent budget cut on the NFR, which funds university research in biology, physics, chemistry and mathematics, as well as four national research laboratories. Threats of wider cuts in the research budget then prompted government officials to consider pulling out of CERN (see Nature 386, 636; 1997). But the research minister Carl Tham was persuaded not to do so.

Now Sweden's particle physicists face the same threat again. Earlier this year the government reorganized its budget lines to give the NFR responsibility for funding international organizations such as CERN and the European Southern Observatory (ESO). The government also imposed a cut in the annual budget of SKr42 million (US\$5.3 million), approximately equal to Sweden's annual subscription to CERN.

The NFR says that continued membership of international research organizations should be Sweden's highest priority if, as looks certain, cuts are not reversed. It is now trying to reach a consensus with universities on the best alternatives for handling the cuts, which come into effect in 2000.

The NFR cannot decide on its own whether or not to leave CERN. This decision lies with the government, which has frequently complained about the high cost of subscriptions to international research organizations. The Swedish particle physics and astronomy communities are served at CERN and ESO, although activities at national and international facilities do not overlap.

The NFR will present its final report to the government in the autumn, when a report from a parliamentary commission on the overall organization of research in Sweden is also due. If it were to leave CERN by 2000, the government would have to announce this by December. Alison Abbott

\title{
Congress remains upbeat on public genome efforts
}

[WASHINGTON] The chairman of a key congressional committee promised last week that funding for the Human Genome Project was not in jeopardy in the light of a recently announced private plan to sequence the entire human genome in only three years.

"I doubt very much that Congress will cut funding" for the project, said Ken Calvert (Republican, California), speaking to officials of the National Institutes of Health (NIH) and Department of Energy (DOE) during a hearing of his House subcommittee on energy and environment, which oversees DOE research.

Witnesses at the hearing generally viewed the joint venture of the Institute for Genomic Research (TIGR) in Rockville, Maryland, and Perkin-Elmer as complementary to the federal project, rather than likely to replace it (see Nature 393, 101 \& 201; 1998).

Craig Venter, TIGR's president, tried to dispel notions of a race, saying his announcement "has led some to speculate that federal funding for the human genome is no longer needed. Nothing could be further from the truth." He called for more money to be spent on government genome research.

Francis Collins and Aristides Patrinos, who head genome research at NIH and DOE, respectively, tried to show how the Human Genome Project differed from Venter's plan. "The genome project is much broader than just the human sequence," said Collins.

The federal effort includes not just delivering raw sequence data, but also producing a high-quality database, distributing information to the scientific community, mapping genomes of other organisms, and studying the ethical, legal and social implications.
Collins said a five-year plan being developed for the federal project will use information from Venter's group (see Nature 393, $399 ; 1998)$. But he admitted it will be difficult for researchers to use the private data until their quality is demonstrated, which may take two or three years.

"The federal effort is fully prepared to adjust its strategy," Collins told the committee. But he added: "We should not drastically alter our strategy until we have more data."

David Galas, who headed DOE's part of the project before becoming president of Chiroscience R\&D in Bothell, Washington, asked for researchers to publish a "first draft" of the human genome "as quickly as possible, whether or not the [Venter] effort contributes... to reaching this goal".

Galas estimated that speeding up publication of a draft version by even a year would save the private sector about $\$ 2$ billion in research costs.

The main dissent came from Maynard Olson, the University of Washington genetics researcher who chairs the NIH review committee for genome research. He predicted that there would be more than 100,000 major gaps in Venter's final assembled sequence.

But the committee members were clearly excited by the TIGR venture. Tim Roemer of Indiana, the senior Democrat on the panel, agreed it was important to be sceptical of promises that "appear too good to be true". But he said that Venter's plan held out the "golden possibility of a private-public partnership that could result in a phenomenal return for science". Tony Reichhardt

\section{Patent office struggles to handle backlog}

[MUNICH] The European Patent Office (EPO) is to recruit an extra 250 patent examiners next year in a bid to keep up with the rapidly growing number of applications.

The number of patent applications filed at the EPO rose by 14 per cent last year to a record 99,800 , partly as a result of lower patent fees. And a backlog of 20,000 patent files is already clogging the in-trays of EPO patent examiners in Munich, The Hague, Berlin and Vienna.

Germany, Great Britain, Switzerland, France and the Netherlands submitted the highest numbers of patent applications last year, and European countries now account for more than half of all applications.

But, according to figures released at a press conference in Munich last week, all of the EPO's 19 member states - as well as the
United States and Japan - have increased their patent activities since the EPO agreed to reduce its official fees two years ago (see Nature 384, 506; 1996).

The largest number of applications was in the category of medical and veterinary technologies, which saw a rise of nearly 15 per cent from 1996, to 6,200. Electronic communications technologies (up 28 per cent) and biochemistry and genetic engineering (up 22 per cent) showed the highest rates of increase.

Ingo Kober, the president of the EPO, told the press conference that the costs of patent applications - which currently average DM60,000 (US\$33,500) — will be reduced further by lowering search costs, a move the EPO hopes will encourage innovation.

Quirin Schiermeier 